\title{
Hydro-Meteorological Monitoring of Tskaltubo (Prometheus) Cave System's Catchment Basin (Caucasus, Western Georgia)
}

\author{
Lezhava Zaza1*, Tsikarishvili Kukuri1, Bolashvili Nana1, Chartolani Giorgi1,2, \\ Chikhradze Nino1,3, Naskidashvili Akaki ${ }^{4}$, Dvalashvili Giorgi ${ }^{2}$, Dzagnidze Suliko², \\ Khomasuridze Zurab ${ }^{2}$ \\ ${ }^{1}$ Vakhushti Bagrationi Institute of Geography, Ivane Javakhishvili Tbilisi State University, Tbilisi, Georgia \\ ${ }^{2}$ Faculty of Exact and Natural Sciences, Ivane Javakhishvili Tbilisi State University, Tbilisi, Georgia \\ ${ }^{3}$ School of Natural Sciences and Engineering, Ilia State University, Tbilisi, Georgia \\ ${ }^{4}$ Akaki Tsereteli State University, Kutaisi, Georgia \\ Email: *zazalezhava@gmail.com
}

How to cite this paper: Zaza, L., Kukuri, T., Nana, B., Giorgi, C., Nino, C., Akaki, N., Giorgi, D., Suliko, D. and Zurab, K. (2017) Hydro-Meteorological Monitoring of Tskaltubo (Prometheus) Cave System's Catchment Basin (Caucasus, Western Georgia). Open Journal of Geology, 7, 1774-1785. https://doi.org/10.4236/ojg.2017.712119

Received: October 30, 2017

Accepted: December 9, 2017

Published: December 12, 2017

Copyright (c) 2017 by authors and Scientific Research Publishing Inc. This work is licensed under the Creative Commons Attribution International License (CC BY 4.0).

http://creativecommons.org/licenses/by/4.0/

\section{(c) (i) Open Access}

\begin{abstract}
Based on the present simultaneous hydrometeorological data and the analysis of the actual materials obtained by our studies, we can suppose the fact of the occurrence of powerful underground floodings in the hydrodynamic system of the Tskaltubo Cave. The simultaneous records of the water levels (discharges) of the underground rivers and atmospheric precipitation show that there are importantly clear peaks in the hydrographs, when the diurnal sums of precipitations reach or exceed $50 \mathrm{~mm}$ in all observation points (in all surface catchment basins defined by us). Though, a long-term observation revealed that only $50 \mathrm{~mm}$ of precipitation diurnal sum is not enough for the formation of strong underground flooding in the cave hydrodynamic system; a rainy period of several days should precede such kind of precipitation so that the soil was well saturated with water. Only under these conditions is expected a powerful flooding. As the analysis of the dangerous flooding formation mechanism showed, what is important is not the abundance of diurnal precipitation and their intensity, but the combination of factors such as: the total amount and duration of precipitation of the predecessor period, precipitation amount during the flooding maximum development days and the coverage rate of the cave system's surface water catchment area.
\end{abstract}

\section{Keywords}

Estavela, Disaster, Siphon, Charge, Flooding 


\section{Introduction}

In 1984 the karst-speleological expedition of the Vakhushti Bagrationi Institute of Geography of the Academy of Sciences of Georgian SSR discovered the previously unknown Tskaltubo karst Cave in the densely populated areas of the Kumistavi Village of Tskaltubo municipality [1].

In subsequent years, the authors of this paper studied the Tskaltubo Cave System's karst-speleological [2] [3] [4] [5], geomorphological-geological [6] [7] and hydrological-hydrogeological [8] [9] [10] [11] features, and the multi-annual hydrometeorological monitoring of the water catchment basin of the cave system was also carried out.

In May 2012, Tskaltubo (Prometheus) Cave was opened to tourists. In the first year of its opening, 80,700 visitors visited the cave; in the subsequent years, the number of visitors only from the European countries exceeded 60,000.

It is noteworthy that there were several cases observed in the study area, when the water from the underground suddenly broke into the main corridor of the Tskaltubo Cave and resulted in the disastrous consequences. In this connection, it was necessary to study the karst-speleology and hydrometeorology of its catchment basin and predict natural disasters-floods.

\section{Research Goal and Methods}

Tskaltubo Cave System and its water catchment basin's hydrodynamic system are characterized by a very important condition, which needs detailed study. In particular, there is a periodically debited Opicho Cave-estavela in the locked karst cave, with the main entrance of the Tskaltubo Cave in its one end. Wide neck directed towards the depth is $12-15$ meters higher than the main entrance of the Tskaltubo Cave, due to which the outburst water from Opicho Cave gets into the cave's main entrance passing through the bottom of the depression. Each water stream formed within the depression rushes towards the main hall of the Tskaltubo Cave, because the main entrance is opened to the lowest point of the depression. Similar case has been recorded several times, when there was an outburst of approximately $30000 \mathrm{~m}^{3}$ of water from the depths of the ground during the Opicho Cave activity period. The outburst water gets into the Tskaltubo Cave's main entrance passing through the bottom of the depression, accompanied sometimes with the disastrous results.

Therefore, the goal of our research was the study of the Tskaltubo (Prometheus) karst Cave System's catchment basin in terms of karst-speleology and to predict flooding-natural phenomena.

Regime observations were arranged on the karst surface and underground water streams during the expedition works. The regime and relationships between surface and underground waters of Tskaltubo Cave System were specified. Based on the materials of multi-annual complete-cycle stationary observation the average monthly and annual charges of karst rivers were identified, as well as the relationships between the fallen atmospheric precipitations and river runoff. 
The runoff's annual fluctuation was studied. In the 12 pre-selected sections, namely, near the place of the cave the rivers flow out and the upper areas of the surface water catchment segments, the water discharge was measured by means of hydrometricrotator-ГР-51. The checkpoints of water and precipitation measuring were arranged. Analysis of so called hydrometeorological course and simultaneous hydrometeorological material (records) were carried out to identify the variability of karst streams discharge.

\section{Description of the Research Object}

Tskaltubo Cave System is $255 \mathrm{~km}$ away from Tbilisi, $16 \mathrm{~km}$ away from Kutaisi and $6 \mathrm{~km}$ away from the resort of Tskaltubo (Figure 1).

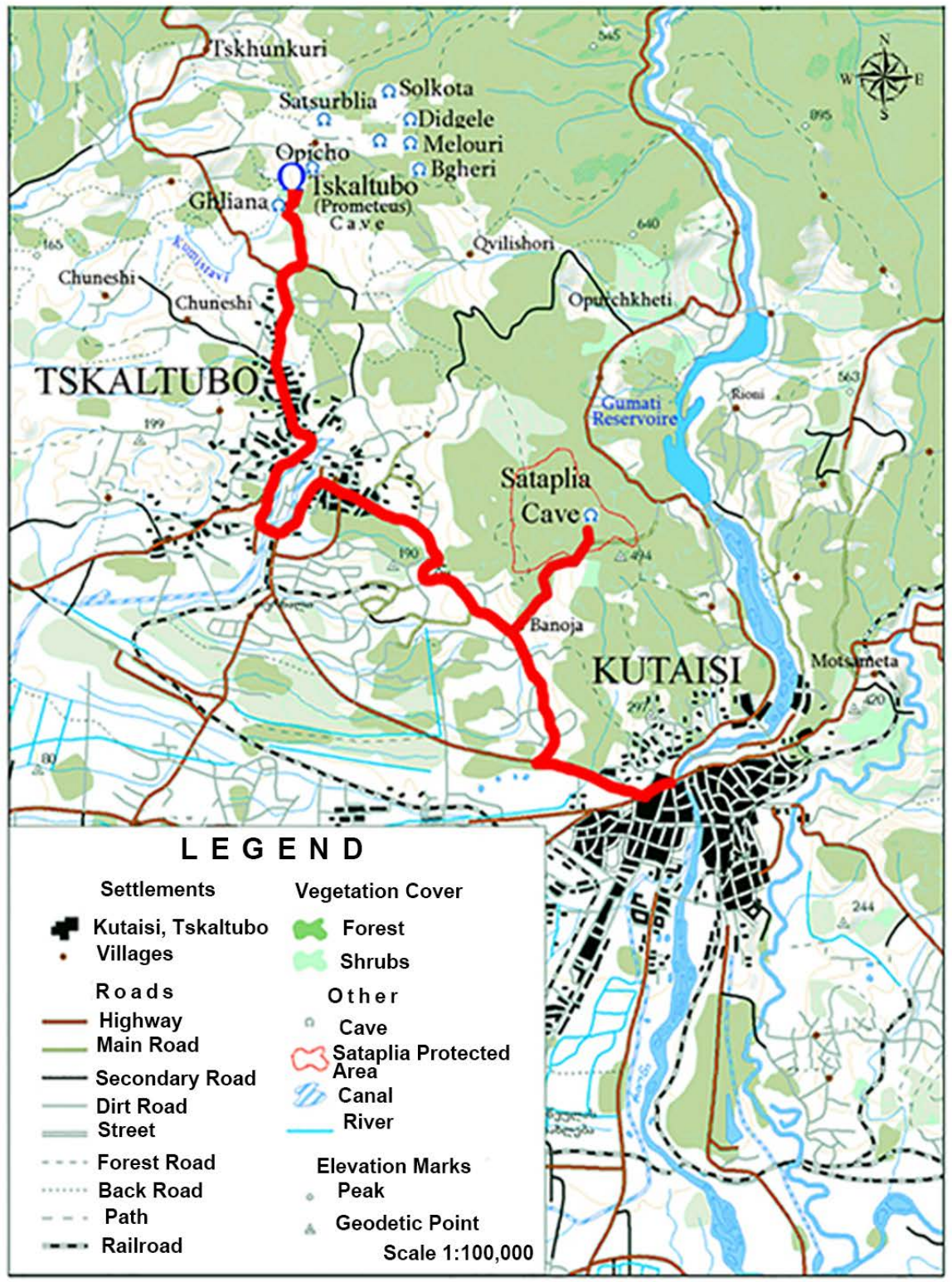

Figure 1. Location of Tskaltubo (Prometheus) Cave System [12]. 
Tskaltubo limestone massif, in the hearth of which the Tskaltubo Cave System is conceived, is located among the rivers of Rioni and Tskhenistskali, in the northern zone of Kolkheti Lowland's hilly relief and belongs to the speleological region of Kvemo Imereti.

The length of the massif is $25 \mathrm{~km}$, width $-12-15 \mathrm{~km}$ and the area-250 km , out of which the $150 \mathrm{~km}^{2}$ is covered by the intense karst territory; it is mainly represented by the gorges of the rivers of Semi and Kumistavi and belongs to the low mountain-forest karst landscape with the moderate humid climate. Here the highest landmark is 768 meters and the height reduces gradually to the south, at the site of Melouri, which is the northeastern continuation of the $\mathrm{Ku}$ mistavi Village. Elevation marks of the site do not exceed $500 \mathrm{~m}$. River. The mark of the Semi riverbed at Melouri before its entering the narrow canyon is 382 meters. The rate of the karst of the territory is so high that there are depicted several streams in the vicinities of the villages of Kumistavi, Kvilishori and Melouri, which cannot find the surface extension and disappear under the ground (Figure 2).

Tskaltubo Cave System and its catchment basin's hydrodynamic system is characterized by the signs characteristic for structures built by karst rocks (monoclinal and southern stretch), which facilitates the movement of groundwater to the mentioned direction. Groundwater streams direction is also determined by the contact areas of karst and nonkarst rocks.

Caves of the region are characterized by well-treated cavities and sharply distinctive meandering corridors and floors, which indicate a slowdown in the upward movement of the territory or an important break in the development process. The rate of the cave formation in the massif is identified not only by the thickness of karst rock sand the frequency of fractures and openness, but also the water storage and discharge conditions under the ground. The massifis mainly characterized by the sub-horizontal cavities of corrosive-erosive type, clearly expressed multilevels and labyrinths, which are geomorphologically sharply

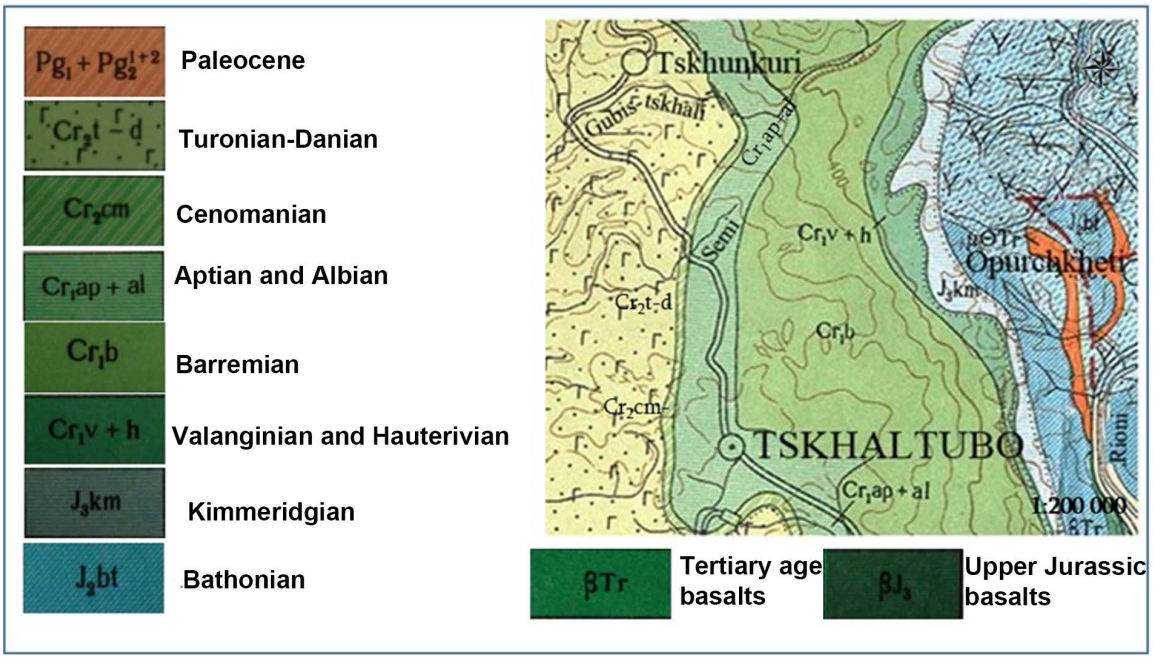

Figure 2. Tskaltubo limestone massif's geological map. 
localized at modern or old erosion network; the cavities include the absorption, underground runoff and discharge areas.

Today the total length of Tskaltubo Cave's surveyed corridors exceed $15 \mathrm{~km}$, but based on the facts, we suppose that it is only a part of many tens of kilometers, and it may be even more extensive cave system. General outline of Tskaltubo Cave has been already clearly identified, which covers about $15 \mathrm{~km}^{2}$ of area built of karst rocks, which is confirmed by the indicative experiments on waters.

In western Georgia, in the conditions of subtropical climate, abundant and long-term rains are common. According to the c. Tskhaltubo and v. Komuli weather stations, the mean annual sums of the atmospheric precipitation are respectively $1818 \mathrm{~mm}$ and $1853 \mathrm{~mm}$ in the cave's extension areal, and the maximum of annual sums are $2200-2300 \mathrm{~mm}$. Monthly sums of precipitation are rather high as well. For example, the monthly maximums exceed $400 \mathrm{~mm}$ (420 $\mathrm{mm}$-January 1950; $414 \mathrm{~mm}$-July 1946, et al.) during the whole observation period according to the materials of $c$. Tskaltubo bioclimatic station. Diurnal sums of the atmospheric precipitation are also high: in c. Tskaltubo-126 $\mathrm{mm}$, in c. Tkibuli-173 mm, etc.

Northernmost boundary of Tskaltubo Cave system is defined by the sublatitudinal segment of the Semi River period, which is characterized by less stable hydrological regime. In hot summer months the water stream can be observed in the bed here and there; alternation of absorption centers is frequent. Therefore, in the upper reaches of the Semi River the river runoff really flows under the ground, but the underground connection between the Semi River and Tskaltubo Cave system is less possible.

One of the important objects of underground karst waters discharged within the research territory is the head of the Tskaltubo River. The Tskaltubo River, which takes its origin from the territory of the city, is mainly fed on karst waters. The runoff measurements were made from the year of 1936 to 1940. Three full annual cycles (1936, 1938 and 1939) of observations are filled up; mean annual discharge is $1.72 \mathrm{~m}^{3} / \mathrm{sec}$. (Table 1) according to the factual material.

The water catchment area before the water measuring checkpoint is indicated as $25 \mathrm{~km}^{2}$. As the observation line is very short, its assessment became necessary with regard to the mean multiannual indicators. The data of the weather station of Kutaisi City was considered the most reliable, on the basis of which the mean annual discharge $-1.49 \mathrm{~m}^{3} / \mathrm{sec}$. of the Tskaltubo River was obtained. The module calculated in accordance with this index of water discharge is equal to 59.6 $\mathrm{L} / \mathrm{sec} . \mathrm{km}^{2}$, which greatly exceeds the zonal index $\left(35 \mathrm{~L} / \mathrm{sec} . \mathrm{km}^{2}\right)$, which should have been for this section of the Rioni River. Obviously, the officially indicated area $\left(25 \mathrm{~km}^{2}\right)$ of the water catchment basin of this river cannot provide the mentioned amount of runoff in the prevailing hydro-meteorological conditions of that place.

The study of the large-scale topographic maps revealed that the surface water catchment area was $49.1 \mathrm{~km}^{2}$. To identify the basin all the negative forms of the 
Table 1. Tskaltubo River's mean monthly discharges $\left(\mathrm{m}^{3} / \mathrm{sec}\right)$ at Tskaltubo City $(\mathrm{H} / \mathrm{M}$ Service).

\begin{tabular}{|c|c|c|c|c|c|c|c|c|c|c|c|c|c|}
\hline Month & I & II & III & IV & $\mathrm{V}$ & VI & VII & VIII & IX & $\mathrm{X}$ & XI & XII & $\begin{array}{c}\text { Mean } \\
\text { annual }\end{array}$ \\
\hline 1936 & 0.51 & 2.15 & 0.67 & 2.20 & 1.21 & 1.26 & 1.75 & 1.44 & 2.41 & 4.25 & 2.32 & 1.53 & 1.81 \\
\hline 1937 & - & - & 1.38 & - & 0.65 & 1.00 & 0.49 & 0.62 & - & 0.82 & 0.52 & - & - \\
\hline 1938 & 2.20 & 2.09 & 5.38 & 3.17 & 1.59 & 2.65 & 0.74 & 0.57 & 0.46 & 0.49 & 1.19 & 0.87 & 1.78 \\
\hline 1939 & 2.39 & 3.80 & 2.71 & 1.34 & 1.30 & 0.89 & 1.14 & 0.72 & 2.37 & 2.30 & 2.12 & 2.06 & 1.93 \\
\hline 1940 & 4.10 & 1.18 & - & - & - & - & - & - & - & - & - & - & - \\
\hline Mean & 2.30 & 2.31 & 2.54 & 2.24 & 1.19 & 1.45 & 1.03 & 0.84 & 1.75 & 1.97 & 1.54 & 1.49 & $1.72^{\star}$ \\
\hline$\%$ & 11.4 & 10.4 & 12.6 & 10.7 & 5.9 & 6.9 & 5.1 & 4.1 & 8.4 & 9.8 & 7.3 & 7.4 & \\
\hline
\end{tabular}

*Calculated according to the mean monthly discharges.

relief were considered, which may have been regarded as the surface water absorption center.

Despite the lack of the observation materials on the runoffs of the Tskaltubo and Gubistskali Rivers, we can say that the mean discharges of the Tskaltubo River (which, as it was noted above, include the three years of a full cycle stationary observations) indicate the stability of the runoff s intra-annual distribution. According to the regime observation materials, the variability of mean monthly discharges is quite low and makes only $30.6 \%$ of the annual amount. Most of the part of the runoff is observed in winter-29.2\% and in spring-29.2\%, while in summer, in the driest period, it is equal to $16.1 \%$.

The first measurements of discharges on the other main discharge objects (outlets of the Kumi and Ghliana Rivers) of the underground karst waters in the vicinity of the Tskaltubo Cave System were carried out on 15 July 1984. On that day the total discharge of the Kumi outlets was $0.532 \mathrm{~m}^{3} / \mathrm{sec}$., while the water temperature was $14.5^{\circ} \mathrm{C}$. Outburst streams from the debiting karst sinkholes and disharge siphon center are gathered in the water gauge section. On the same day the Ghliana River's underground water discharge was $0.074 \mathrm{~m}^{3} / \mathrm{sec}$. and the temperature $-13.8^{\circ} \mathrm{C}$ at the place of the outlet on the surface.

Further research revealed that the Kumi River runoff is characterized by a high fluctuation; on July 20,1984, the discharge of the stream flowing out from the underground was $2.1 \mathrm{~m}^{3} / \mathrm{sec}$., while on August $9-15 \mathrm{~m}^{3} / \mathrm{sec}$. The latter was stipulated because of the heavy rains.

An interesting fact was observed on June 18, 1986. Suddenly (13 h 45 min) a turbid stream rushed to the edge of periodically debiting Opicho Cave, which is located 12 - $15 \mathrm{~m}$ higher than the main entrance of Tskaltubo Cave. Earlier, in the wide neck of Opicho Cave was rising above the water level with the speed of $0.2 \mathrm{~m} / 1 \mathrm{~min}$. After 15 minutes, a small stream turned into the powerful and mighty river and flew to the Tskaltubo Cave's main corridor through depression bottom and flooded the cave. Maximum discharge of the outburst water reached $5.645 \mathrm{~m}^{3} / \mathrm{sec}$. 
With this intensity the water was flowing out during the 40 minutes. After the 55 minutes of beginning the outburst, the water amount began decreasing and at 15:30 the outburst was completely stopped.

During the whole time (105 minutes) of Opicho Cave's activity there was an outburst of 30 thousand $\mathrm{m}^{3}$ of water from the depth of the ground. The outburst of almost half of this mass was during those 40 minutes, when the water stream had the maximum discharge. The water temperature was $14.2^{\circ} \mathrm{C}$ (Figure 3).

Data of Tskhaltubo weather station show that there was $78.2 \mathrm{~mm}$ of precipitation the day, when there was the outburst of water from Opicho debiting Cave. Torrential rain caused a sharp rise of levels in the nearby rivers and the flooding wave overflew the river banks. Great flooding occurred in Tskaltubo Cave's major discharge centers - on the rivers of Kumi and Ghliana. The water of the mentioned rivers was coming as a fast stream; the overall dischargeby visual assessment was approximately $35-40 \mathrm{~m}^{3} / \mathrm{sec}$. including the Ghliana share-5 $\mathrm{m}^{3} / \mathrm{sec}$. The flooding began in 1986 on the night of June 17-18. It should be noted that the most part $(78.2 \mathrm{~mm})$ of the total amount of precipitation fallen on June 18, had fallen in the morning at 10 o'clock. During the next 24 hours, when the amount of precipitation was only $9.2 \mathrm{~mm}$, flooding ended quickly and in the afternoon of June 19, the Kumi River discharge had fallen to $2.2 \mathrm{~m}^{3} / \mathrm{sec}$.

\section{Results and Discussion}

Practice has demonstrated that it is necessary to conduct the direct observations on specific object within the actual water catchment basin. Otherwise, it is impossible to analyze the precipitation related floodings, and moreover, the reliability of forecasting groundwater flooding is being reduced.

Based on the analysis, it is identified that the river runoff fluctuation and atmospheric precipitation rhythm seems to be fitted each other, which in this case is quite noteworthy, because the mentioned river flow is mainly formed at the expense of atmospheric precipitation.

Regime stationary observations were conducted on the hydrometeorological elements of the major centers of the underground karst water discharges and

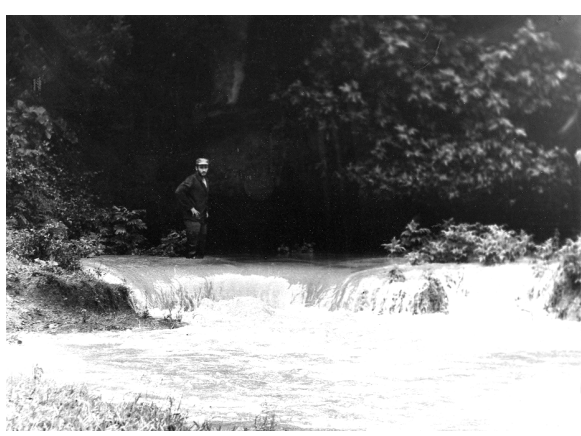

(a)

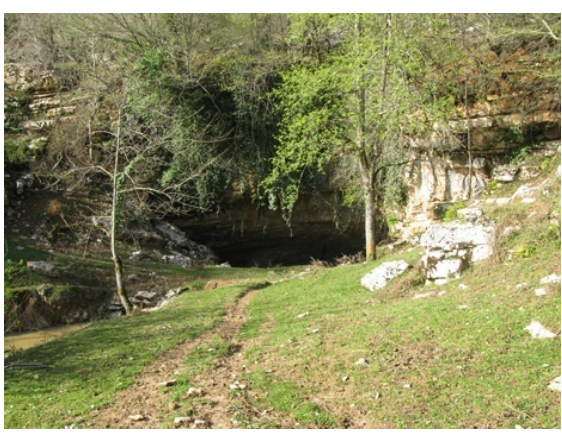

(b)

Figure 3. Outburst of water mass from Opicho Cave-estavela (to the left) and the entrance in the usual conditions (to the right) in June 18, 1986. 
within the water catchment basin of Tskaltubo Cave System since 1987. The observations covered the full annual cycle. Three rain gauges were installed: at the checkpoint 1-at the upper area of the surface catchment basin, at the checkpoint 2-at the central zone of the surface water absorption and at the checkpoint 3-near the outlets of the underground rivers. It was added by the materials of the Tskaltubo basic weather station, which was located hypsometrically at a lower elevation. The water gauge checkpoints were arranged at the outlets of the rivers of Kumi and Ghliana (Table 2).

The water gauge checkpoint of Kumi River-Kvilishori Village was arranged $8.5 \mathrm{~km}$ away from the siphon discharge center at the end of Tskaltubo Cave. Outburst streams from the debiting sinkholes were also gathered at the checkpoint. The water gauge checkpoint of Ghliana River-Kvilishori Village was arranged 10 meters away from the river outlet from the cave. Observations on water discharges were conducted by means of the hydrometric rotator ГР-55 (Table 3) at both checkpoints.

On basis of analysis of the existing simultaneous hydro-meteorological data we can express our preliminary views on the occurrence of a powerful underground floodings in the Tskaltubo Cave's hydrodynamic system.

Table 2. Amount of atmospheric precipitation in the Tskaltubo Cave vicinities in 1987 by months.

\begin{tabular}{|c|c|c|c|c|c|c|c|c|c|c|c|c|c|}
\hline Months & I & II & III & IV & $\mathrm{V}$ & VI & VII & VIII & IX & $\mathrm{X}$ & $\mathrm{XI}$ & XII & $\begin{array}{c}\text { Total } \\
\text { annual }\end{array}$ \\
\hline \multicolumn{14}{|c|}{ Checkpoint 1} \\
\hline $\mathrm{mm}$ & 450 & 162 & 203 & 303 & 47 & 110 & 171 & 148 & 82 & 88 & 209 & 359 & 2332 \\
\hline$\%$ & 19.0 & 7.0 & 88 & 13 & 2 & 4.8 & 7.4 & 6.4 & 3.6 & 3.5 & 9.0 & 15.5 & \\
\hline $\begin{array}{l}\text { Diurnal } \\
\text { maximum }\end{array}$ & 70 & 30 & 62 & 75 & 11 & 29 & 71 & 70 & 25 & 22 & 74 & 47 & \\
\hline \multicolumn{14}{|c|}{ Checkpoint 2} \\
\hline $\mathrm{mm}$ & 393 & 134 & 198 & 226 & 41 & 110 & 188 & 167 & 85 & 84 & 212 & 348 & 2186 \\
\hline$\%$ & 18 & 6.1 & 9.0 & 10.3 & 1.9 & 5.0 & 8.6 & 7.6 & 3.9 & 3.8 & 9.8 & 16.0 & \\
\hline $\begin{array}{l}\text { Diurnal } \\
\text { maximum }\end{array}$ & 94 & 23 & 56 & 32 & 11 & 26 & 76 & 71 & 23 & 20 & 70 & 48 & \\
\hline \multicolumn{14}{|c|}{ Checkpoint 3} \\
\hline $\mathrm{mm}$ & 375 & 132 & 200 & 209 & 40 & 116 & 182 & 159 & 80 & 90 & 214 & 360 & 2157 \\
\hline$\%$ & 17.2 & 6.1 & 9.3 & 9.7 & 1.9 & 5.4 & 8.4 & 7.4 & 3.7 & 4.2 & 9.8 & 16.6 & \\
\hline $\begin{array}{c}\text { Diurnal } \\
\text { maximum }\end{array}$ & 88 & 22 & 59 & 30 & 10 & 25 & 79 & 62 & 24 & 23 & 80 & 47 & \\
\hline \multicolumn{14}{|c|}{ Tskaltubo City } \\
\hline $\mathrm{mm}$ & 334 & 124 & 165 & 234 & 38 & 144 & 142 & 184 & 80 & 93 & 154 & 368 & 2060 \\
\hline$\%$ & 16.2 & 6.0 & 8.0 & 11.3 & 1.8 & 7.0 & 6.9 & 8.9 & 3.9 & 4.5 & 7.5 & 17.9 & \\
\hline $\begin{array}{c}\text { Diurnal } \\
\text { maximum }\end{array}$ & 53 & 22 & 54 & 43 & 15 & 33 & 57 & 94 & 24 & 24 & 39 & 51 & \\
\hline
\end{tabular}


Table 3. Mean, maximum and minimum water discharges $\left(\mathrm{m}^{3} / \mathrm{sec}\right.$.) of the underground rivers of Kumi and Ghliana in 1987 by months.

\begin{tabular}{|c|c|c|c|c|c|c|c|c|c|c|c|c|c|}
\hline Discharge & I & II & III & IV & $\mathrm{V}$ & VI & VII & VIII & IX & $\mathrm{X}$ & $\mathrm{XI}$ & XII & $\begin{array}{c}\text { Mean } \\
\text { annual }\end{array}$ \\
\hline \multicolumn{14}{|c|}{ Kumi River-Kvilishori Village } \\
\hline Mean monthly & 1.15 & 0.74 & 0.87 & 0.79 & 0.44 & 0.43 & 0.58 & 0.46 & 0.43 & 0.42 & 0.63 & 0.79 & 0.64 \\
\hline$\%$ & 14.9 & 9.6 & 11.3 & 10.2 & 5.7 & 5.6 & 7.5 & 5.6 & 5.6 & 5.4 & 8.2 & 16.2 & \\
\hline Maximum & 29.0 & 1.49 & 9.52 & 3.54 & 0.57 & 0.74 & 14.6 & 2.44 & 1.25 & 0.61 & 5.73 & 15.5 & 29.0 \\
\hline Minimum & 0.49 & 0.55 & 0.56 & 0.55 & 0.37 & 0.36 & 0.40 & 0.34 & 0.37 & 0.38 & 0.41 & 0.43 & 0.34 \\
\hline \multicolumn{14}{|c|}{ Ghliana River-Kvilishori Village } \\
\hline Mean monthly & 0.54 & 0.17 & 0.22 & 0.21 & 0.05 & 0.06 & 0.12 & 0.06 & 0.05 & 0.06 & 0.16 & 0.23 & 0.16 \\
\hline$\%$ & 28.0 & 8.8 & 11.4 & 10.8 & 2.4 & 3.1 & 6.2 & 3.1 & 2.4 & 3.1 & 8.3 & 11.9 & \\
\hline Maximum & 10.8 & 0.69 & 2.10 & 2.34 & 0.07 & 0.18 & 7.60 & 1.81 & 0.64 & 0.14 & 4.31 & 8.05 & 3.22 \\
\hline Minimum & 0.11 & 0.07 & 0.08 & 0.07 & 0.04 & 0.04 & 0.04 & 0.04 & 0.04 & 0.04 & 0.06 & 0.05 & 0.04 \\
\hline
\end{tabular}

Simultaneous records of 1987 (Table 2) of the water discharges (Table 3) of the underground rivers of Kumi and Ghliana show that the significantly distinct peaks were occurred then, when the diurnal sums of precipitation reached or exceeded $50 \mathrm{~mm}$ at every checkpoints. For example, by the data of the upper first rain gauge, in April as if the conditions were created for the occurrence of a flooding. On April 26, there was recorded $75 \mathrm{~mm}$ of precipitation, while in the previous three days $-80 \mathrm{~mm}$. In addition, these precipitations coincided a very favorable long-term rainy background (from 13 to 20 April, the rain did not stop and its amount reached $111 \mathrm{~mm}$ ). But at the other checkpoints such abundant rainfall was not observed. On April 26 at the checkpoint 2 was recorded $7.5 \mathrm{~mm}$, while at the lower checkpoint $3-27.6 \mathrm{~mm}$. On that day there was no precipitation at all in Tskaltubo. As a result, very low peaks were registered on the hydrographs of underground rivers.

As it turned out, the plentiful, but diurnal precipitations, which cover the entire catchment of the cave, is not enough for occurrence of the dangerous flooding. In August 10, 1987, at all checkpoints were registered large amount of precipitation: checkpoint $1-70 \mathrm{~mm}$, checkpoint $2-70.8 \mathrm{~mm}$, checkpoint $3-62.3$ $\mathrm{mm}$ and Tskaltubo City- $94.2 \mathrm{~mm}$. But as a long dry period preceded these precipitations, they had unimportant impact on the levels of the underground rivers. During the August 10 the maximum discharge did not exceed $2.44 \mathrm{~m}^{3} / \mathrm{sec}$. at the outlets of the Kumi River and $1.86 \mathrm{~m}^{3} / \mathrm{sec}$. - at the outlets of the Ghliana River.

Almost the same thing happened in November 3, when the high rainfall was recorded on the mentioned rain gauge (checkpoint $1-73.6 \mathrm{~mm}$, checkpoint 2 $70.2 \mathrm{~mm}$, checkpoint $3-79.5 \mathrm{~mm}$ and Tskaltubo City-39.1 mm). This was preceded by several rainy days, having slightly softened the soil after the 12-day dry period, but not so much to create favorable conditions for the occurrence of a powerful flooding. The maximum discharges of this day were: the Kumi River- 
$5.73 \mathrm{~m}^{3} / \mathrm{sec}$, and the Ghliana River- $4.31 \mathrm{~m}^{3} / \mathrm{sec}$.

Particularly high floodings were noted in January, July and December during the annual cycle of observation on the main centers of discharge of the underground waters of Tskaltubo Cave hydrodynamic system.

In January 31, 1987, maximum discharges of the underground rivers of Kumi and Ghliana were accordingly, $29 \mathrm{~m}^{3} / \mathrm{sec}$ and $10.8 \mathrm{~m}^{3} / \mathrm{sec}$. Almost in the same regime was activated the periodically debiting Opicho Cave. This flooding was preceded by a week-long rainy period. It rained within the entire surface water catchment basin. Precipitation sums of the previous period in the checkpoints were from 52.8 to $41.3 \mathrm{~mm}$. Flooding wave began sharp increase in January 29, when the diurnal amount of precipitation reached 58.0 - $35.9 \mathrm{~mm}$. 93.6 - 50.0 $\mathrm{mm}-93.6 \mathrm{~mm}$ was recorded in the day of occurrence of further discharges. Diurnal maximum of precipitations- $93.6 \mathrm{~mm}$ was recorded at the checkpoint 2 or in the middle of the surface water catchment basin.

Two other high floodings, which passed in July and December, also occurred on the background of the previous rainy period.

Seven rainy days preceded the July flooding with the total amount of precipitation from 70.4 to $54.0 \mathrm{~mm}$ on different observation stations. In July 8 and 9 , during the days of flooding peaks, $122.2 \mathrm{~mm}$ of rainfall was registered in the checkpoint 2 in total. This figure is less than the precipitation sum of those three days of January, when $185.8 \mathrm{~mm}-14.6 \mathrm{~m}^{3} / \mathrm{sec}$. was registered in the same checkpoint. Diurnal sum of precipitation was also less $-75.6 \mathrm{~mm}$ at the checkpoint 2 than in the corresponding day of January $(93.6 \mathrm{~mm})$. There was no outburst of water from Opicho Cave in these days.

In December 4 the continuous rains began, due to which the flooding occurred in December 11, when the maximum discharges on the rivers of Kumi and Ghliana were respectively $15.5 \mathrm{~m}^{3} / \mathrm{sec}$. and $8.05 \mathrm{~m}^{3} / \mathrm{sec}$. The flooding wave was sharply raised in December 10, while the next day it reached the highest level. Predecessor precipitation sum from 4 to 9 December at the various checkpoints was from $113.4 \mathrm{~mm}$ to $88.3 \mathrm{~mm}$. In December 10 and 11, the days of active development of flooding, the amount of precipitation was $96.9 \mathrm{~mm}$ at the checkpoint 2 , and when flooding reached its maximum, the amount of precipitation was $49.3 \mathrm{~mm}$. But Opicho Cave-estavela was not activated even in this case.

Similar works (observations) were carried out in order to study and specify the relationship of Tskaltubo Cave System's surface and ground water regimes in the following years as well (Table 4), where there was approximately the same picture as in 1987.

\section{Conclusions}

Simultaneous records of the underground rivers' water levels (discharges) and atmospheric precipitation show that there are importantly clear peaks on the hydrographs, when the diurnal sums of precipitation reach or exceed $50 \mathrm{~mm}$ in every point of observation (in all surface water catchment basin identified by us). 
Table 4. Measured water discharges in the river sections of Tskaltubo massif in 2008.

\begin{tabular}{|c|c|c|c|c|c|c|}
\hline No. & Section & $\begin{array}{l}\text { Hydrometric } \\
\text { rotator, turn/sec. }\end{array}$ & $\begin{array}{l}\text { Correlation } \\
\text { coefficient }\end{array}$ & $\begin{array}{l}\text { Water section } \\
\text { area, } \mathrm{m}^{2}\end{array}$ & $\begin{array}{l}\text { Water flow speed, } \\
\mathrm{m} / \mathrm{sec} \text {. }\end{array}$ & $\begin{array}{c}\text { Water discharge, } \\
\mathrm{m}^{3} / \mathrm{sec} .\end{array}$ \\
\hline 1 & $\begin{array}{l}\text { Mill pond at the Kumi vaucluse } \\
\text { after the opening of dam }\end{array}$ & 11.1 & 0.7 & 0.20 & 1.3 & 0.180 \\
\hline 2 & Kumistskali 2nd outlet & 6.48 & 0.7 & 0.12 & 0.8 & 0.067 \\
\hline 3 & Kumi (1st stream) & 4.84 & 0.7 & 0.16 & 0.6 & 0.067 \\
\hline 4 & Kumi (2nd stream) & 3.22 & 0.7 & 0.09 & 0.4 & 0.025 \\
\hline 5 & Kumi (3rd stream) & 5.57 & 0.7 & 0.14 & 0.7 & 0.069 \\
\hline 6 & Ghliana (at the cave) & 1.75 & 0.7 & 0.65 & 0.2 & 0.091 \\
\hline 7 & Ghliana (outside the cave) & 2.91 & 0.7 & 0.04 & 0.4 & 0.011 \\
\hline 8 & Jibilauri & 3.33 & 0.7 & 0.16 & 0.4 & 0.045 \\
\hline 9 & Kvilishori Cave. Jibilauri vaucluse & 5.48 & 0.7 & 0.04 & 0.7 & 0.020 \\
\hline 10 & $\begin{array}{l}\text { Melouri. Didghele River, at the entrance } \\
\text { of the cave, over the waterfall }\end{array}$ & 2.62 & 0.7 & 0.04 & 0.3 & 0.008 \\
\hline 11 & Bgheri & 5.08 & 0.7 & 0.44 & 0.6 & 0.180 \\
\hline 12 & $\begin{array}{l}\text { Semi River (at the Tskhunkuri Village), } \\
\text { beyond the bridge }\end{array}$ & 6.67 & 0.7 & 0.20 & 0.8 & 0.110 \\
\hline
\end{tabular}

Long-term observation revealed that only $50 \mathrm{~mm}$ of precipitation diurnal sum is not enough for the formation of strong underground flooding in the cave hydrodynamic system; a rainy period of several days should precede such kind of rain so that the soil was well saturated with water. Only under these conditions is expected a powerful flooding.

Thus, according to the available regime material, the diurnal maximum of atmospheric precipitation may exceed $100 \mathrm{~mm}$ regime was, while the intensity of rainstorms may reach $4 \mathrm{~mm} / \mathrm{min}$. But as the analysis of the dangerous flooding formation mechanism shows, important is not the abundance of diurnal precipitation and their intensity, but a combination of factors such as: the total amount and duration of precipitation of the predecessor period, precipitation amount during the flooding maximum development days and the coverage rate of the cave system's surface water catchment area.

Tskaltubo Cave has now a lot of visitors and provision of their safety is a main issue. The real danger, which can happen to people in the cave, is a sudden flooding. Opicho phenomenon requires more basic study.

Tskaltubo Cave System's hydrometeorological monitoring requires proper attention and organization. We consider it necessary the creation of the permanent regime of hydro-meteorological network in the vicinity of cave system, which will provide the identification of diurnal levels, debits, solid deposition charges and chemical composition (including the $\mathrm{CO}_{2}$ ) of the rivers (Kumi, Ghliana, Tskaltubo outlet, Semi, etc.).

\section{References}

[1] Jishkariani, J., Tsikarishvili, K., Kobulashvili, T. Jamrishvili, A., Kapanadze, V. 
(1986) The Latest Research Results of Tskaltubo Cave System. Reports Theses of Scientific Session of Vakhushti Bagrationi Institute of Geography, Metsniereba, Tbilisi, 31-32.

[2] Tintilozov, Z.K. (1976) Karst Caves of Georgia (Morphological Analysis). Book. Editor Tsereteli D.V. Metsniereba, Tbilisi.

[3] Tatashidze, Z., Jishkariani, J., Tsikarishvili, K., Jamrishvili, A., Kapanadze, V., Kobulasvili, T. and Geladze, G. (2002) Tskaltubo Cave System-The Largest Karst Cavity in the Imereti Region. Bulletin of the Georgian Academy of Sciences, 166, 514-517.

[4] Tatashidze, Z.K., Jishkariani, V.M., Tsikarishvili, K.D., Jamrishvili, A.R., Kapanadze, V.M., Kobulashvili, T.G. and Geladze, G.V. (2004) New Karst Cave in Tskaltubo Vicinity (Western Georgia), in the Book Peshchery (Caves), Interuniversity Collection of Scientific Transactions, Perm, 48-52.

[5] Tatashidze, Z., Tsikarishvili, K., Jishkariani, J., Jamrishvili, A., Geladze, G. and Lominadze, G. (2009) Tskaltubo Cave System (Editor, Prof. Ramin Gobejishvili), Petite, Tbilisi.

[6] Liponava, K. (1985) Tskaltubo limestone Massif's Relief Development Features. Mountainous Areas Productive Forces Development Problems. Reports Theses, Tbilisi, 14-15.

[7] Tsikarishvili, K., Lezhava, Z., Asanidze, L., Bolashvili, N., Chikhradze, N. and Chartolani, G. (2015) Geomorphologic Features of Sataplia-Tskaltubo Limestone Massif. Earth Sciences. Special Issue: Modern Problems of Geography and Anthropology, 4, 108-112.

[8] Vladimirov, L. and Gigineishvili, G. (1973) Water Balance Patterns in the Karst Region of the Greater Caucasus. Abstracts of papers submitted to the 6 th International Congress of Speleology, Olonouc, Czechoslovakia.

[9] Gigineishvili, G.N. (1979) Karst Waters of the Greater Caucasus and the Main Problems of Karst Hydrology. Metsniereba, Tbilisi.

[10] Gigineishvili, G., Tatashidze, Z. and Tsikarishjvili K. (2007) Geographic-Hydrological Arguments on Possible Expansion of the Tskaltubo Cave System. Bulletin of the Georgian Academy of Sciences, 175, 67-70.

[11] Lezhava, Z., Bolashvili, N., Tsikarishvili, K., Asanidze, L. and Chikhradze, N. (2015) Hydrological and Hydrogeological Characteristics of the Platform Karst (Zemo Imereti Plateau, Georgia). Sinkholes and the Engineering and Environmental Impacts of Karst. Proceedings of the 14th Multidisciplinary Conference, Rochester, 5-9 October 2015, 93-100.

[12] Lanchava, O. and Tsikarishvili, K. (2016) Tskaltubo (Prometheus) Cave System. Publishing House Tbilisi State University, Tbilisi. 